DOI https://doi.org/10.32689/maup.philol.2021.2.2

УДК $811.112 .2 ’ 373.74$

\title{
Ангеліна ГОЯН
}

асистент кафедри германського, загального і порівняльного мовознавства факультету іноземних мов, Чернівецький національний університет імені Юрія Федьковича, вул. Коцюбинського, 2, м. Чернівці, Україна, 58012

ORCID: 0000-0003-1993-5029

\section{Anhelina HOYAN}

Assistant Professor of German, General and Comparative Linguistics, Department of Foreign Languages, Yuri Fedkovych Chernivtsi National University, Kotsyubynskoho str., 2, Chernivtsi, Ukraine, 58012 ORCID: 0000-0003-1993-5029

\section{ФУНКЦІОНАЛЬНИЙ АСПЕКТ ФРАЗЕОЛОГІЗМІВ У ДИСКУРСІ ЕКОНОМІЧНИХ РУБРИК СУЧАСНОЇ НІМЕЦЬКОЇ ПРЕСИ}

\section{THE FUNCTIONAL ASPECT OF IDIOMS IN THE DISCOURSE OF BUSINESS AND ECONOMY SECTIONS IN CONTEMPORARY GERMAN NEWSPAPER}

\begin{abstract}
У статті досліджуються особливості застосування та основні прагматичні функиії фразеологізмів у дискурсі економічних рубрик сучасної німецької преси. На основі статистичного аналізу встановлено, для яких видань вживання фразеологізмів є найбільш характерним. Метою статті є дослідження функиіонального аспекту фразеологізмів у дискурсі економічних рубрик сучасної німецької преси. Наукова новизна. Інтенсивний розвиток лінгвістики змусив мовознавиів звернути увагу на роль різноманітних мовних одиниць $і$ категорій у різних типах дискурсу. Адже, щзоб пізнати його природу, необхідно пізнати властивості елементів, що иого утворюють. Під поняттям «дискурс економічних рубрик преси» ми розуміємо всю сукупність текстів з економічної тематики, щзо проголошуються через засоби масової інформації. Фразеологічні одинииі (ФО) займають в иьому дискурсі помітне місие, оскільки несуть особливе комунікативне навантаження. Висновки. В результаті дослідження з'ясовано, щзо фразеологізми в економічних статтях несуть значне прагматичне навантаження: допомагають влучно описати економічну ситуачію та її учасників, схарактеризувати їх діяльність та стан справ, емоційно та виразно підкреслити й очінити важливу інформацію у тексті, допомагають читачеві сформувати власну думку, яка, тим не менш, часто залежить від намірів журналіста, щзо вдало оперує експресивними ФО.
\end{abstract}

Ключові слова: фразеологізм, економічний дискурс, статистика.

The article examines the features of application and the main pragmatic functions of phraseology in the discourse of economic headings of the modern German press. Based on statistical analysis, it is established for which publications the use of phraseology is most characteristic. The aim of the article is to study the functional aspect of phraseology in the discourse of economic sections of the modern German press. Scientific novelty. The intensive development of linguistics has forced linguists to pay attention to the role of different language units and categories in different types of discourse. After all, to know its nature, it is necessary to know the properties of the elements that make it up. By the term "discourse of economic sections of the press" we mean the whole set of texts on economic issues, which are proclaimed through the media. Phraseological units (PH) occupy a prominent place in this discourse, because they carry a special communicative load. Conclusions. The study found that phraseology in economic articles carry a significant pragmatic load: help to accurately describe the economic situation and its participants, describe their activities and state of affairs, emotionally and clearly emphasize and evaluate important information in the text, help the reader to form their own opinion. which, however, often depends on the intentions of the journalist, who successfully operates expressive FD.

Keywords: phraseology, economic discourse, statistics.

Актуальність проблеми. У сучасному мовознавстві термін дискурс вже достатньо популярний і широко вживаний (А. Бєлова, О. Бєссонова, Т. ван Дейк, К. Кусько, К. Кремш, I. Морозова, М. Полюжин, А. Приходько, Т. Скуратівська, Ч. Філмор та ін.). У найсучасніших дослідженнях дискурс розглядається як «специфічна для конкретної культури i соціуму мовна реалізація, яка конструює пев- ний погляд на соціальне спілкування, як на символічне відтворення інтерсуб' єктивності» [6, с. 242]. Інше визначення характеризує дискурс як «сукупність мовленнєвих та мисленнєвих дій комунікантів, пов' язану з пізнанням, осмисленням і презентацією світу мовцем та реконструкцією мовної картини світу продуцента реципієнтом» [2, с. 66]. Отже, в обох випадках дослідження дискурсу передбачає 
вивчення не абстрактної мовної системи, а живої мови в умовах реального спілкування. Саме функціонування мови в реальному часі, просторі та соціальних умовах є дискурсом.

Метою статті є дослідження функціонального аспекту фразеологізмів у дискурсі економічних рубрик сучасної німецької преси.

Виклад основного матеріалу. Інтенсивний розвиток лінгвістики змусив мовознавців звернути увагу на роль різноманітних мовних одиниць і категорій у різних типах дискурсу. Адже, щоб пізнати його природу, необхідно пізнати властивості елементів, що його утворюють. Під поняттям «дискурс економічних рубрик преси» ми розуміємо всю сукупність текстів 3 економічної тематики, що проголошуються через засоби масової інформації. Фразеологічні одиниці (ФО) займають в цьому дискурсі помітне місце, оскільки несуть особливе комунікативне навантаження. «Вони засвоюються краще, ніж вільні словосполучення 3 погляду розуміння буденного життя, оскільки вони влучніші, об'ємніші й переконливіші для сприйняття, тобто мають експресивніший вплив» [7, с. 94]. О. Селіванова, зі свого боку, вказує на інтердискурсивні властивості фразеологізмів, які здатні входити до складу будь-яких дискурсивних практик, конструювати їх та модифікувати [10, с. 121]. ФО, на відміну від лексем і стандартних словосполучень, позначають не стільки «фрагмент» дійсності, скільки дають йому оцінку i характеристику. Як відзначає О. Селіванова, «фразеологічні знаки вносять до комунікативного процесу цілий світ сенсів, особливу образність, виразність, експресивність, аксіологічність, що грунтуються на комплексі відчуттів та уявлень народу» [10, с. 12]. Власне факт високої образності і експресивності пояснює широке застосування фразеологізмів у публіцистиці.

З іншого боку, побутує думка, що мова ділової комунікації не передбачає вживання емоційної лексики, ніби вона $є$ неметафоричною і буквально відображає дійсність та наміри комунікантів. I, тим не менш, будь-яке спілкування не може бути абсолютно позбавленим емоцій. Удавана відсутність емоцій часто вуалюється так званою ідіоматичністю, яка в цьому випадку розуміється як ускладненість, іншими словами - сконцентрованість, способу вираження змісту [1; с. 51]. Образність мовлення суб'єкта, який не прямо висловлює свої почуття, примушує адресата думати логічно, намагатися зрозуміти зміст сказаного. У мовленні ділових партнерів часто присутня додаткова емоційна інформація, яка здебільшого виражається через загальновідоме метафоричне значення.

Дискурсивний аналіз статей економічного та комерційного спрямування також підтвердив, що подібні вирази, активно заповнюють цей мовний простір. До такого ж висновку дійшли у своїх працях й інші дослідники $[4$, с. $185 ; 8$, с. 3]. Безперечно, у текстах ділового спрямування цілком виправданою $\epsilon$ велика кількість штампів та рутинних виразів, адже офіційна сфера завжди передбачає певну шаблонність та безособовість. 3 іншого боку, ці ж самі тексти відзначилися великою фразеологічною насиченістю. Оригінальне пояснення цьому дає В. Карасик: «вживаючи кліше, мовець ніби надягає маску представника інституційної групи, але, водночас, фразеологічні одиниці є засобом самовираження мовця» [4, с. 186]. Матеріалом нашого дослідження слугували фразеологічні одиниці німецької мови, відібрані методом суцільної вибірки з наступних журналів та газет останніх П'яти років: "Die Zeit" [12], "Frankfurter Allgemeine Zeitung" [13] (FAZ), "Sьddeutsche Zeitung" (SZ) [15], "Rheinischer Merkur" (RM) [14], "Der Spiegel" [11]. Загальний обсяг вибірки складає понад 5 мільйонів словоформ, серед яких зафіксовано 17665 вживань фразеологічних одиниць.

Щоб статистично довести переважання того чи іншого виду ФО в економічних рубриках певної газети чи журнали ми скористалися статистичними методиками, а саме критерієм $\chi 2$ та коефіцієнтом взаємної спряженості Чупрова (К), за допомогою яких можна визначити наявність зв'язків між певними явищами та міру цих зв'язків [5, с. 87]. Ми використовували формулу суми $\chi 2$ для альтернативних (чотирипільних) таблиць, утворених двома рядками і двома стовпчиками, шляхом об'єднання рядків і стовпчиків у багатопільній таблиці: Величини коефіцієнта взаємної спряженості можуть отримувати значення від 0 до +1 , причому, чим більшим є цей показник, тим більшою вважається міра існуючого зв'язку між аналізованими явищами. Його значущість встановлюється відповідно до величини ұ2 [5, с. 91].

Серед досліджуваного матеріалу більше однієї п’ятої усіх фразеологізмів зафіксовано у статтях з економічної та комерційної тематики. Кількісні та статистичні результати подані в табл. 1 (порожні клітинки вказують на відсутність значущих статистичних зв'язків).

Як свідчать дані табл. 1, показники вживаності ФО у різних газетах суттєво 
різняться між собою. Найменше фразеологізмів, пов'язаних $з$ економічною тематикою зафіксовано у журналі

«Spiegel» $(13 \%)$, що є цілком логічним, адже у журналі, який є переважно суспільнополітичним виданням, економічні рубрики $\epsilon$ мало репрезентованими. Дещо більша кількість ФО зафіксована в економічних статтях тижневика «RM» $(17 \% ; 6,8$ вживань ФО на 1 стор.). Проте найоб'ємніше фразеологізми представлені у щоденних газетах, де a, b, c, $\mathrm{d}$ - емпіричні величини чотирипільних таблиць, $\mathrm{N}$ - загальна кількість спостережень.

Для чотирипільних таблиць мінімальною величиною $\chi 2$, при якій зв'язок між явищами прийнято рахувати значимим, $\epsilon$ величина 3,84 при $\mathrm{P}=0,05$. При рівні значущості $\mathrm{P}=$ 0,01 величина $\chi 2$ повинна бути не меншою ніж 6,63. Загалом сполучення слів (явищ), міра зв'язку яких більша або рівна 3,84, можна вважати стандартними (стабільними) $[5$, c. 91$]$.

Сума $\chi^{2} є$ тим більшою, чим більше емпіричні величини відхиляються від теоретичних. Якщо отримані суми $\chi 2$ при відповідних ступенях свободи перевищують критичні, то так звана нульова гіпотеза (про відсутність зв'язку між величинами) відхиляється.

Однак сума $\chi 2$ дозволяє виявити лише наявність або відсутність зв'язку між досліджуваними величинами, але не показує ступінь цього зв'язку. Цю величину можна визначити за допомогою коефіцієнта взаємної спряженості Чупрова К для альтернативних таблиць:

$$
\mathrm{K}=. \sqrt{\frac{x^{2}}{N}}
$$

«SZ» $(25,6 \%)$ та «FAZ» $(32,8 \%)$ - в обох газетах вживається по 11 ФО на 1 сторінку. Статистичний аналіз виявив значимі зв'язки ФО в усіх виданнях крім «Zeit». Таким чином можна стверджувати, що вживання ФО $\epsilon$ характерним для економічних рубрик наступ- них видань: «Rheinischer Merkur», «Frankfurter Allgemeine Zeitung», «Süddeutsche Zeitung» та «der Spiegel». Причому найбільш значущою $\epsilon$ вживаність фразеологізмів у газеті «FAZ», де величина К виявляє найвищий показник $(0,1)$.

Що ж стосується прагматичного аспекту аналізованих фразеологізмів, то їх основною функцією $\epsilon$ привернення й утримування уваги, зацікавлення читача та здійснення впливу на нього. Уміло оперуючи образними фразеологічними одиницями, журналіст підкреслює важливу інформацію, робить логічний наголос на важливому, дає свою оцінку подіям та створює емоційно-експресивну виразність тексту.

Передовсім ФО $\epsilon$ метафорами, що образно характеризують конкретну економічну ситуацію:

реалії економічної дійсності. Наприклад:

in einerZwickmühlestecken [SZ,24.03.09, c. бути у складному становищі,

Tanz um das goldene Kalb [SZ, 21.03.09, с. 34] - танок навколо золотого бика; sich am eigenen Schopf aus dem Sumpf gezogen haben [FAZ, 23.03.09, с. 17] - витягти себе за волосся з болота.

2) поведінку учасників економічної діяльності по відношенню один до одного. Це може бути наприклад, допомога один одному: j-n unter die Arme greifen [FAZ, 23.03.09,

c. 18]; j-m auf die Sprünge helfen [SZ, 24.03.09,

c. 19] - підтримати кого-небудь, допомогти матеріально;

j-m den Rücken freihalten [SZ, 24.03.09, c.

28] - підстрахувати кого-небудь;

Або ж навпаки - пригнічення конкурентів:

- j-n in die Knie zwingen [SZ, 24.03.09, c.

$28]$ - змусити кого-небудь впасти навколішки;

- j-n zur Kasse bitten [FAZ, 24.03.09, c. 9]

вимагати гроші у когось, притягнути до відповідальності;

Таблиця 1

Частота вживаності ФО в економічних рубриках

\begin{tabular}{|c|c|c|c|c|c|c|c|}
\hline \multicolumn{2}{|r|}{ Рубрика } & RM & Zeit & FAZ & $\mathrm{SZ}$ & Spiegel & Усього \\
\hline \multirow{2}{*}{ 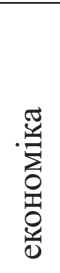 } & кількісно & $\begin{array}{c}766 \\
(17 \%) \\
\end{array}$ & $\begin{array}{c}817 \\
(20,8 \%) \\
\end{array}$ & $\begin{array}{c}1094 \\
(32,8 \%) \\
\end{array}$ & $\begin{array}{c}855 \\
(25,6 \%) \\
\end{array}$ & $\begin{array}{c}340 \\
(13 \%) \\
\end{array}$ & $\begin{array}{c}3875 \\
(22 \%) \\
\end{array}$ \\
\hline & статистично & $\begin{array}{l}\chi 2=80,8 \\
K=0,06\end{array}$ & & $\begin{array}{c}\chi 2=283,1 \\
\mathrm{~K}=0,1\end{array}$ & $\begin{array}{c}\chi 2=32 \\
K=0,04\end{array}$ & $\begin{aligned} \chi 2 & =137,5 \\
\mathrm{~K} & =0,08\end{aligned}$ & \\
\hline & Усього & 4472 & 3925 & 3336 & 3342 & 2590 & 17665 \\
\hline
\end{tabular}


3) критика поведінки окремих учасників економічної діяльності. Наприклад:

die Manager schlagen über die Stränge [FAZ, 23.03.09, с. 12] - менеджери переходять усі межі;

4) характеристика учасників економічної діяльності та їхній стан справ: die alten Hasen [SZ, 28.03.09, с. 33] - старі зайці - для характеристики досвідчених спеціалістів у певній галузі;

fette Katzen [SP, 19.05.03, с. 86] - жирні коти образна характеристика багатих магнатів; er ist die dickste Kuh in j-s Stall [SP, 27.01.03, c. 75] - найтовстіша корова у стайні - про людину, яка приносить комусь найбільший прибуток; Серед прикладів ФО економічних рубрик $є$ багато таких, які містять в собі метафоричні порівняння, для влучнішої характеристики економічної ситуації. Це образи:

- транспорту, наприклад: etw. auf den Kurs bringen [SZ, 28.03.09, с. 38] - навести на курс; aus dem Ruder laufen [SZ, 28.03.09, c. 28];

- водної стихії: mit j-m in einem Boot sitzen [SZ, 21.03.09, с. 24] - сидіти з кимось в одно- му човні (бути пов'язаним з ким-н., бути в однаковому становищі); j-m das Wasser abgraben [FAZ, 28.03.09, с. 52] - підкопувати когось; j-m Wind aus den Segeln nehmen [SZ, 24.03.09, с. 20] - забирати у когось вітер 3 вітрил (заважати комусь);

- спорту: mit den Muskeln spielen [FAZ, 18.03.09, с. 21] - грати м'язами (показувати свою силу);

- гри у карти: gute Karten haben [FAZ 28.03.09, с. 19] - мати хороші карти; die Karten werden neu gemischt [FAZ, 18.03.09, c. 45] наново змішувати карти.
Так само, для опису економічної ситуації часто використовуються економічні вирази, що прийшли у фразеологію 3 фахової мови, наприклад:

rote Zahlen schreiben [SZ, 28.03.09, c. 39] (rote Zahlen - 'кількісні дані, що показуютьдефіцитбалансу'[Пророченко,Гаврись, c. 335)];

schwarzeZahlen schreiben[SZ,21.03.09, c. 24]

(відсутність дефіциту балансу). Обидва словосполучення вживаються для характеристики фінансового стану учасників економічної діяльності.

Отже, фразеологізми в економічних статтях несуть значне прагматичне навантаження: допомагають влучно описати економічну ситуацію та їі учасників, схарактеризувати їх діяльність та стан справ, емоційно та виразно підкреслити й оцінити важливу інформацію у тексті, допомагають читачеві сформувати власну думку, яка, тим не менш, часто залежить від намірів журналіста, що вдало оперує експресивними ФО.

Вживання ФО є характерним для економічних рубрик "Rheinischer Merkur", "Frankfurter Allgemeine Zeitung", "Süddeutsche Zeitung" та "der Spiegel" та не суттєвим у газеті "Zeit". Найбільш статистично значущою $є$ вживаність фразеологізмів у газеті “FAZ”, яка також відзначається найбільшою фразеологічною насиченістю.

Перспективу проведеного дослідження вбачаємо у виявленні модифікацій компонентного складу ФО економічних рубрик та виявленні особливостей функціонування ФО в інших видах дискурсу.

\section{Література:}

1. Баранов А.Н., Добровольский Д.О. Аспекты теории фразеологи. Москва : Знак, 2008. 656 с. (Studia philologica).

2. Врабель Т.Т. Проблема визначення дискурсу і тексту. Стратегії наративного дискурсу. Проблеми романо-германської філології: збірник наукових праџь. Ужгород : ЛІРА, 2006. С. 64-72.

3. Гаврись В.І., Пророченко О.П. Німецько-український фразеологічний словник. Київ : Радянська школа, 1981. Т. І. 416 с. Т. II. 328 с.

4. Козлова Е.А. Эмоциогенные фрагменты картины мира экономики и бизнеса в фразеологической репрезентации. II Междунар. науч. конф. (Белгород, 7-9 сентября 2010 г.) : Фразеология, познание и культура : сб. докл. в 2 т. Белгород : Изд-во БелГУ, 2010. Т.1. Фразеология и познание. 410 с. С. 185-189.

5. Левицкий В.В. Квантитативные методы в лингвистике. Черновцы : Рута, 2004. 190 с.

6. Макаров М.Л. Основы теории дискурса. Москва : Гнозис, 2003. 280 с.

7. Мізін К.І. Компаративна фразеологія : монографія. Кременчук : ПП Щербатих О.В., 2007. 168 с.

8. Пономаренко В.А. Фразеологические единицы в деловом дискурсе (на материале английского и русского языков) : автореф. дисс... канд. фил. наук. Краснодар, 2007. 20 с.

9. Селиванова Е.А. Синергетика фразеологического дискурса: параметры самоорганизации. Фразеология, познание и культура: сб. докл. 2-й Междунар. науч. конф. (Белгород, 7-9 сентября 2010 г.) в 2 т. : отв. ред. проф. Н.Ф. Алефиренко. Белгород : Изд-во БелГУ, 2010. Т.1. : Фразеология и познание. 410 c. C. $117-121$.

10. Селіванова О. Нариси з української фразеології (психокогнітивний та етнокультурний аспекти). Київ, Черкаси : Брама, 2004. 276 с. 
11. Der Spiegel. № 5 від 27.01.03, № 21 від 19.05.03, № 19 від 05.05.03, № 20 від 12.05.03, № 2 від 10.01.05. 2004-2008 pp.

12. Die Zeit. №№ 5, 12, 43, 46, 51. 2004-2008 pp.

13. Frankfurter Allgemeine Zeitung. №№ 1-20. 2008-2009 pp.

14. Rheinischer Merkur. №№ 30, 31, 35, 37, 44, 45, 50, 51, 52. 2004-2006 pp.

15. Süddeutsche Zeitung. №№ 1-30. 2008-2009 pp.

\section{References:}

1. Baranov, A.N., Dobrovolskyi, D.O. (2008). Aspekty teoryy frazeolohy [Aspects of phraseology theory]. Moscow : Znak, 656 p. (Studia philologica). [in Russian].

2. Vrabel, T.T. (2006). Problema vyznachennia dyskursu i tekstu. Stratehii naratyvnoho dyskursu. [The problem of defining discourse and text. Strategies of narrative discourse]. Problemy romano-hermanskoi filolohii: zbirnyk naukovykh prats - Problems of Romano-Germanic philology: a collection of scientific works. Uzhhorod: LIRA, 2006. P. 64-72. [in Ukrainian].

3. Havrys, V.I., Prorochenko, O.P. (1981). Nimetsko-ukrainskyi frazeolohichnyi slovnyk [German-Ukrainian phraseological dictionary]. Kyiv: Radianska shkola, 1981. T. I. 416 p. T. II. 328 p. [in Ukrainian].

4. Kozlova E.A. (2010). Emotsiogennye fragmenty kartiny mira ekonomiki i biznesa v frazeologicheskoy reprezentatsii [Emotional fragments of the picture of the world of economics and business in phraseological representation]. II Mezhdunarodnaya nauchnaya konferentsiya: Frazeologiya, poznanie i kul tura: sbornik dokladov - II International Scientific Conference: Phraseology, Cognition and Culture: Collection of Reports. Belgorod: Izd-vo BelGU. T.1. Frazeologiya i poznanie. 410 p. P. 185-189. [in Russian].

5. Levitskiy, V.V. (2004) Kvantitativnye metody v lingvistike [Quantitative methods in linguistics]. Chernovtsy: Ruta. 190 p. [in Russian].

6. Makarov, M.L. (2003). Osnovy teorii diskursa [Foundations of the theory of discourse]. Moscow: Gnozis. 280 p. [in Russian].

7. Mizin, K.I. (2007). Komparatyvna frazeolohiia: monohrafiia [Comparative phraseology: monograph]. Kremenchuk: PP Shcherbatykh O.V., 168 p. [in Ukrainian].

8. Ponomarenko, V.A. (2007). Frazeologicheskie edinitsy v delovom diskurse (na materiale angliyskogo i russkogo yazykov). [Phraseological units in business discourse (based on the material of English and Russian languages)]. Extended abstract of candidate's thesis. Krasnodar. 20 p. [in Russian].

9. Selivanova, E.A. Sinergetika frazeologicheskogo diskursa: parametry samoorganizatsii. [Synergetics of phraseological discourse: parameters of self-organization]. II Mezhdunarodnaya nauchnaya konferentsiya: Frazeologiya, poznanie i kul'tura: sbornik dokladov - II International Scientific Conference: Phraseology, Cognition and Culture: Collection of Reports. Belgorod: Izd-vo BelGU. T.1. Frazeologiya i poznanie. 410 p. P. 185-189. [in Russian].

10. Selivanova, O. (2004). Narysy z ukrainskoi frazeolohii (psykhokohnityvnyi ta etnokulturnyi aspekty). [Essays on Ukrainian phraseology (psychocognitive and ethnocultural aspects)]. Kyiv, Cherkasy: Brama, 276 p. [in Ukrainian].

11. Der Spiegel. № 5 від 27.01.03, № 21 від 19.05.03, № 19 від 05.05.03, № 20 від 12.05.03, № 2, 10.01.05. 2004-2008.

12. Die Zeit. №№ 5, 12, 43, 46, 51. 2004-2008.

13. Frankfurter Allgemeine Zeitung. №№ 1-20. 2008-2009.

14. Rheinischer Merkur. №№ 30, 31, 35, 37, 44, 45, 50, 51, 52. 2004-2006.

15. Süddeutsche Zeitung. №№ 1-30. 2008-2009. 